\title{
Reproductive dynamics of swordfish (Xiphias gladius) in the southwestern Indian Ocean (Reunion Island). Part 1: oocyte development, sexual maturity and spawning
}

\author{
François Poisson ${ }^{1, \mathrm{a}}$ and Christian Fauvel $^{2}$ \\ 1 IFREMER, Centre de Recherche halieutique méditerranéen et tropical, BP 171, avenue Jean Monnet, 34203 Sète Cedex, France \\ 2 IFREMER, laboratoire Recherches aquacoles, chemin de Maguelone, 34250 Palavas-les-Flots, France
}

Received 9 June 2008; Accepted 12 December 2008

\begin{abstract}
The reproductive dynamics of swordfish (Xiphias gladius) was investigated from catches of the Reunion Island-based longline swordfish fishery between $19-25^{\circ} \mathrm{S}$ and $48-54^{\circ} \mathrm{E}$. Thus, 1727 swordfish (size range $75-289 \mathrm{~cm}$, lower jaw-to-fork length, LJFL) were sampled on board commercial fishing vessels during the period of May 1998 to January 2001. Reproductive activity was assessed using macroscopic gonad characteristics, trends of gonadal indexes for both sexes, oocyte size-frequency distributions and microscopic investigation of oocyte development stages. Size at first maturity $\left(L_{50}\right)$ for female and male swordfish was estimated in Indian Ocean for the first time. $L_{50}$ was estimated at $170 \mathrm{~cm}$ and $120 \mathrm{~cm}$ (LJFL) for females and males, respectively. Spawning occurred from October to April in the vicinity of Reunion Island where sex ratio of caught populations fluctuated seasonally. The seasonal changes in sex ratio and the incidence of larger individuals at the beginning of the spawning season provide some preliminary indications of synchronized movements of swordfish between spawning grounds and neighboring regions. Our results add significantly to knowledge about the reproductive biology of swordfish in the southwestern Indian Ocean. An overview of the available information on reproductive biology and dynamics of swordfish in Indian Ocean and eastern Pacific indicated that spawning activity is localized in discrete areas, and showed that there is incomplete information on spawning grounds in this extended area.
\end{abstract}

Key words: Reproduction / Sex ratio / Spawning season / Histology / Size at first maturity / Seasonal distribution / Swordfish / Xiphias gladius / Indian Ocean

\begin{abstract}
Résumé - Dynamique de la reproduction chez l'espadon (Xiphias gladius) du sud-ouest de l'océan Indien (île de La Réunion). 1 : développement ovocytaire, maturité sexuelle et ponte. La dynamique de la reproduction est étudiée chez des espadons (Xiphias gladius) capturés dans l'océan Indien, entre 19-25 ${ }^{\circ}$ Sud et $48-54{ }^{\circ}$ Est, par les palangriers de l'île de La Réunion. Ainsi, 1727 espadons de tailles comprises entre 75 et $289 \mathrm{~cm}$ (de l'extrémité de la mâchoire inférieure à la fourche caudale) ont été échantillonnés à bord de navires professionnels, de mai 1998 à janvier 2001. La reproduction est évaluée en analysant : les caractéristiques macroscopiques des gonades, l'évolution des indices gonadiques des deux sexes, les distributions de fréquence de taille des ovocytes et le développement des ovocytes au niveau microscopique. La taille à première maturité sexuelle $\left(L_{50}\right)$ des espadons de l'océan Indien est estimée pour la première fois; elle atteint $170 \mathrm{~cm}$ pour les femelles et $120 \mathrm{~cm}$ pour les mâles. La saison de ponte s'étend d'octobre à avril aux abords de l'île tandis que le sexe-ratio fluctue de façon saisonnière. Les variations saisonnières du sexe-ratio et l'apparition de grands individus au début de la saison de ponte suggèrent des déplacements d'espadons entre cette zone de ponte et les régions voisines. Nos résultats apportent des informations fondamentales sur la biologie de la reproduction de l'espadon dans le sud-ouest de l'océan Indien. L'analyse de la bibliographie concernant biologie et la dynamique de la reproduction de l'espadon dans l'océan Indien et dans le Pacifique Est indique que l'activité de ponte est très localisée et que la connaissance des aires de pontes est encore incomplète dans cette région étendue.
\end{abstract}

\section{Introduction}

In the Indian Ocean, catches of swordfish (Xiphias gladius) increased markedly after 1990 up to a peak of $35000 \mathrm{t}$ in

\footnotetext{
a Corresponding author: Francois.Poisson@ifremer.fr
}

1998 , when the maximum catch for the species was recorded. By 2007, twenty countries were reporting catches at the Indian Ocean Tuna Commission (IOTC). On the basis of stock indicators, IOCT Scientific Committee concluded that the current level of catch (about $32000 \mathrm{t}$ ) is unlikely to be sustainable. 
IOTC also highlighted that swordfish life history characteristics, like high age-at-maturity, long life and sexual dimorphism, make this species particularly vulnerable to overexploitation (Anonymous 2007).

Studies on swordfish life-history, and particularly reproduction, are extremely difficult as this species is highly migratory and cannot be held in captivity. Characterization of "spawning regions" (Hoey 1986) requires a large number of samples covering an ocean-wide area (Arocha et al. 2007; Ortiz 2000; Mejuto 2006).

During the last decade, several scientific national and multilateral programs focusing on swordfish fisheries have been undertaken in various countries on the Indian Ocean (Anonymous 2007). Despite the growing scientific interest for swordfish, data gathered on the life history of this species in the Indian Ocean is scarce and patchy. Most of the studies conducted in limited geographical areas, especially in the western Indian Ocean, and no comprehensive study of swordfish reproduction dynamics has been carried out over the entire Indian Ocean.

The first identification of potential spawning grounds in the Indian Ocean was inferred from a small number of observations of hydrated females (Yabe et al. 1959), from larvae collection (Lütken 1880, cited in Palko et al. 1981; Bogorov et Rass 1961, cited in Palko et al. 1981; Gorbunova 1969; Nishikawa and Ueyanagi 1974; Kondritskaya et al. 1970; Nishikawa et al. 1985), and from the occurrence of swordfish juveniles in the stomach contents of tunas and marlins (Yabe et al. 1959). More recently, Mejuto et al. (2006) proposed reproduction areas based on data from gonadal indexes and sex ratios at size.

To clarify the seasonal maturation dynamics and reproductive biology of swordfish (Xiphias gladius) in the vicinity of Reunion Island, we monitored the gonadal development of individuals caught by the domestic longline fishery fleet over 32 consecutive months.

The objectives of the present study were to characterize a new spawning area for swordfish and to better describe its reproductive features in this area through a long term survey. To achieve these objectives, we aimed (1) to link the developmental stages of oocytes described by histology to macroscopic characteristics of gonads, (2) to define the spawning seasonality of swordfish in the vicinity of Reunion Island, (3) to estimate size at first maturity $\left(L_{50}\right)$ for females and males, and (4) to review all available information about reproductive biology of swordfish in the Indian and western Pacific Oceans. By then, crossing this information with seasonal catch data, we aimed to establish a hypothesis of reproductive movement patterns and to provide preliminary indications of swordfish movements between spawning grounds and neighboring biological regions.

\section{Materials and methods}

\subsection{Measurements at sea and gonad collection}

Scientific observers on board commercial longline fishing vessels sampled swordfish between May 1998 and January
2001 (except in September 1998, February 1999, and December 2000). Swordfish were caught by longlines set at night and retrieved at dawn the following day, at a depth ranging from 60 to $150 \mathrm{~m}$, between $19-25^{\circ} \mathrm{S}$, and $48-54^{\circ} \mathrm{E}$ (Fig. 1).

Before being dressed by fishers, curved lower jaw-to-fork length (LJFL) and eye-to-fork length (EFL) were recorded to the nearest $\mathrm{cm}$, using measuring tape.

A total of 1727 swordfish were sampled of which 1107 were female and 620 male, ranging from 75 to $289 \mathrm{~cm}$ and from 79 to $208 \mathrm{~cm}$ (LJFL), respectively.

LJFL was used for fish size assessment and $L_{50}$ estimate. EFL was only used to establish gonadal index (GI) in order to determine reproductively active females according to Hinton et al. (1997).

Whole gonads were placed in a plastic bag, labeled with a sample number, stored on ice until arrival at the laboratory, and matched to the corresponding carcass. The data collected for each fish included the date, location of the set, and all other information on the fishing conditions. Two subsamples $\left(2 \mathrm{~cm}^{3}\right)$ were taken from the largest ovary and fixed (1) in buffered Gilson's fluid (Lowerre-Barbieri and Barbieri 1993) for oocyte size distribution study and (2) in 5\% formalin for histology.

Fieldwork maturity scales were established for both sexes based on visual examination and confirmed by histology. Seven gonad maturation stages were identified for females and 5 for males following macroscopic characteristics derived from criteria developed by Cayré and Farrugio (1996) for the skipjack tuna (Tables 1 and 2). This macroscopic classification was only used for temporal analysis of the relative prevalence of maturity stages, mainly to assess the occurrence of hydrating or hydrated gonads (stage 5) in spawning females.

\subsection{Laboratory processing}

\subsubsection{Histology}

From the monthly fish samples, 62 ovary samples were processed. Subsamples fixed in formalin were transferred to Bouin-Holland's solution (Gabe 1968) for 48 hours. Oocytes were dehydrated in successive baths of alcohol and embedded in paraffin. They were sectioned transversely to $5 \mu \mathrm{m}$ and stained with Dominici's method (in Gabe 1968). Finally, they were examined under a microscope (magnification between 10 and 100).

\subsubsection{Oocyte diameter distribution}

Gonads were weighed to the nearest $0.1 \mathrm{~g}$ when below $400 \mathrm{~g}$ and to nearest $5 \mathrm{~g}$ when above $400 \mathrm{~g}$. Ovary samples were stored for six months in Gilson's fluid. The medium was changed every month and the vial vigorously shaken to ensure complete penetration and rupture of connective tissues. As Gilson's induces shrinkage of oocytes (Stéquert and Ramcharrun 1995; Mugnier 1996), we monitored oocyte diameter reduction at a daily interval over 30 days in 3 ovaries with vitellogenic oocytes. Average oocyte shrinkage was calculated separately for batches of oocytes ranging from 0.5 to $1 \mathrm{~mm}$ diameter and oocytes larger than $1 \mathrm{~mm}$. Most of the total 

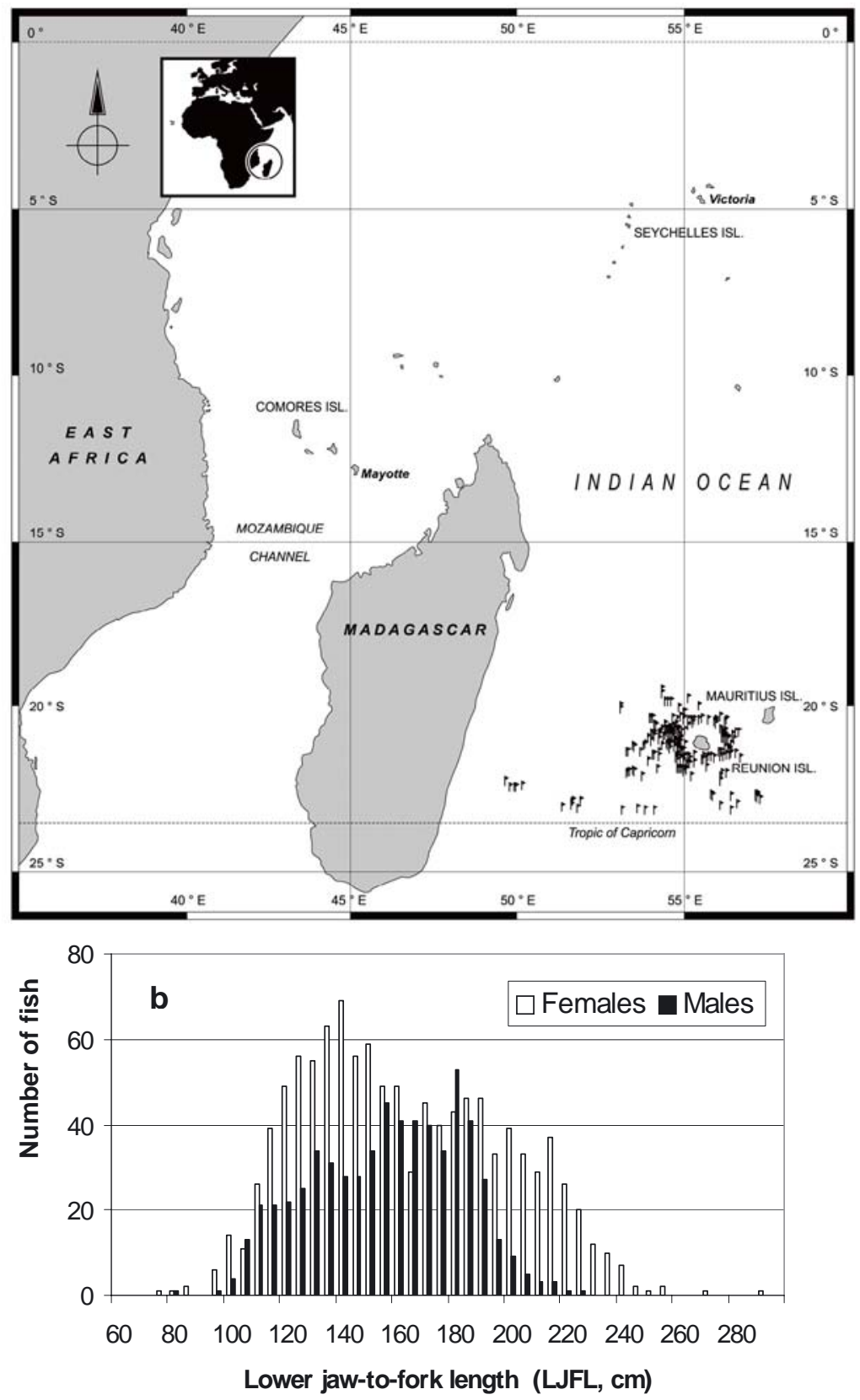

Fig. 1. (a) Locations where sampled swordfish were caught between May 1998 and January 2001 (each symbol shows a fishing operation); (b) Size frequency distribution (5-cm classes) for swordfish sampled in the vicinity of Reunion Island during the same period on board domestic longline vessels.

shrinkage of oocytes fixed in Gilson's fluid occurred within the first four days. The rates of shrinkage at 30 days, after which oocyte diameter was stable, were $20 \%$ for oocytes between 0.5 to $1 \mathrm{~mm}$ and $10 \%$ for the batch of the oocytes larger than $1 \mathrm{~mm}$. These percentages were used as correction factors in the oocyte diameter distribution studies.

Oocytes were first teased out with a pair of needles. Diameters of a subsample of 100-200 oocytes then were measured automatically using an image analysis software package (Visilog 5.1, Noesis) in combination with a microscope equipped with a CCD camera (Sony, type XC77C 2/3) and a
Pentium $400 \mathrm{MHz}$ computer equipped with a Matrox-Meteor graphics card.

Ovary developmental stages and measurements of the largest oocyte size mode were determined from 4 females for each reproductive stage.

\subsubsection{Gonadal indexes}

Females. The reproductive status of females greater than $165 \mathrm{~cm}$ (LJFL) (body length at sexual maturity in the Pacific 
Table 1. Macroscopic maturity scale for female swordfish (Xiphias gladius) from the vicinity of Reunion Island over the study period.

\begin{tabular}{|c|c|c|c|}
\hline Stage & Maturity scale & $\begin{array}{l}\text { Oocyte stage* } \\
\text { (histology) }\end{array}$ & $\begin{array}{l}\text { Gonadal index } \\
\text { mean } \pm \text { SD } \\
\text { (sample size) }\end{array}$ \\
\hline 0 & $\begin{array}{l}\text { Sex determination is impossible by } \\
\text { visual examination. Gonads are } \\
\text { close to vertebral column, tiny, } \\
\text { translucent and undeveloped. }\end{array}$ & Previtellogenic & \\
\hline 1 & $\begin{array}{l}\text { Immature: sex can be identified. } \\
\text { Gonads are small, tubular, firm, } \\
\text { pinkish, oocytes not detectable } \\
\text { without magnification. }\end{array}$ & Previtellogenic & $0.72 \pm 0.14(39)$ \\
\hline 2 & $\begin{array}{l}\text { Developing: Gonads are tubular, } \\
\text { white and measured about } 1 / 2 \text { of the } \\
\text { abdominal cavity. individual } \\
\text { oocytes are not yet visible. The } \\
\text { lumen is clearly visible in section. }\end{array}$ & Previtellogenic & $0.89 \pm 0.15(307)$ \\
\hline 3 & $\begin{array}{l}\text { Maturing: gonads are reddish and } \\
\text { vascularized and contain opaque } \\
\text { oocytes, clearly visible when ovary } \\
\text { is cut. }\end{array}$ & $\begin{array}{l}\text { Vitellogenic } \\
200-500 \mu \mathrm{m}\end{array}$ & $0.98 \pm 0.14(327)$ \\
\hline 4 & $\begin{array}{l}\text { Ripening: Gonads are soft } \\
\text { and turgescent and highly vascularized } \\
\text { and occupy about } 3 / 4 \text { of the ventral } \\
\text { cavity. Oocytes are creamy white } \\
\text { and individualized. }\end{array}$ & $\begin{array}{l}\text { Vitellogenic } \\
200-800 \mu \mathrm{m}\end{array}$ & $1.49 \pm 0.2(77)$ \\
\hline 5 & $\begin{array}{l}\text { Spawning: Hydrated cells are } \\
\text { dominant runs under moderate } \\
\text { pressure. }\end{array}$ & $\begin{array}{l}\text { Migrating nucleus and } \\
\text { hydration } \\
200-1550 \mu \mathrm{m}\end{array}$ & $1.61 \pm 0.11(112)$ \\
\hline 6 & $\begin{array}{l}\text { Spent or resting: Features are } \\
\text { related to the elapsed time since the } \\
\text { last spawning. Gonads are slack, } \\
\text { dark red to greyish, haemorrhagic } \\
\text { zones can be observed }\end{array}$ & $\begin{array}{l}\text { Zona radiata breakdown } \\
\text { and resorption }\end{array}$ & $1.22 \pm 0.16(234)$ \\
\hline
\end{tabular}

* This refers to the most advanced stage of oocyte development inside the ovary.

Table 2. Macroscopic maturity scale for male swordfish (Xiphias gladius) from the vicinity of Reunion Island over the study period.

\begin{tabular}{cl}
\hline Stage & Males \\
\hline 0 & $\begin{array}{l}\text { Sex determination is impossible by visual examination. } \\
\text { Gonads are close to vertebral column, tiny, translucent } \\
\text { and undeveloped. }\end{array}$ \\
& $\begin{array}{l}\text { Maturing: sex can be identified. Gonads are pinkish, } \\
\text { thin and frayed with a flattened knife-edged shape. }\end{array}$ \\
2 & $\begin{array}{l}\text { Maturation: gonads are creamy white reddish and } \\
\text { vascularized turgescent but no sperm is visible when } \\
\text { cut. }\end{array}$ \\
3 & $\begin{array}{l}\text { Ripe: } \text { Like stage } 2 \text { but testes run under moderate } \\
\text { pressure. } \\
\text { Spent } \text { or resting: Gonads are highly vascularized, dark } \\
\text { red to brownish. }\end{array}$ \\
\hline
\end{tabular}

Ocean, DeMartini et al. 2000), was assessed by the gonadal index $(G I)$ after Hinton et al. (1997):

$$
G I=\ln (G W) / \ln (0.9286 L J F L-7.5824)
$$

where $G W$ : gonad weight $(\mathrm{g})$
Males. The gonadal index $(G I)$ was calculated as:

$$
G I=10^{4}\left(G W / E F L^{3}\right)
$$

where EFL: eye-to-fork length (cm).

\subsubsection{Size at first maturity $\left(L_{50}\right)$}

Size at first maturity was estimated using swordfish of both sexes caught during the spawning season described in the present study, 553 females and 282 males.

For both sexes, the length at which $50 \%$ of all individuals were sexually mature $\left(L_{50}\right)$ was estimated from the percentage of reproductively active individuals in each 5-cm length class. The relation between the size and maturity was fitted by a non linear estimation, using the least squares estimation procedure. The maturity-length relationship describes a two logistic curve as follows:

$$
P_{n}=100[1 /(1+\exp (a-b L J F L))]
$$

where $P_{n}$ is the proportion of mature individuals within the size class $n$ (body length, $L J F L$ ), the parameters $a$ and $b$ were to be estimated. 


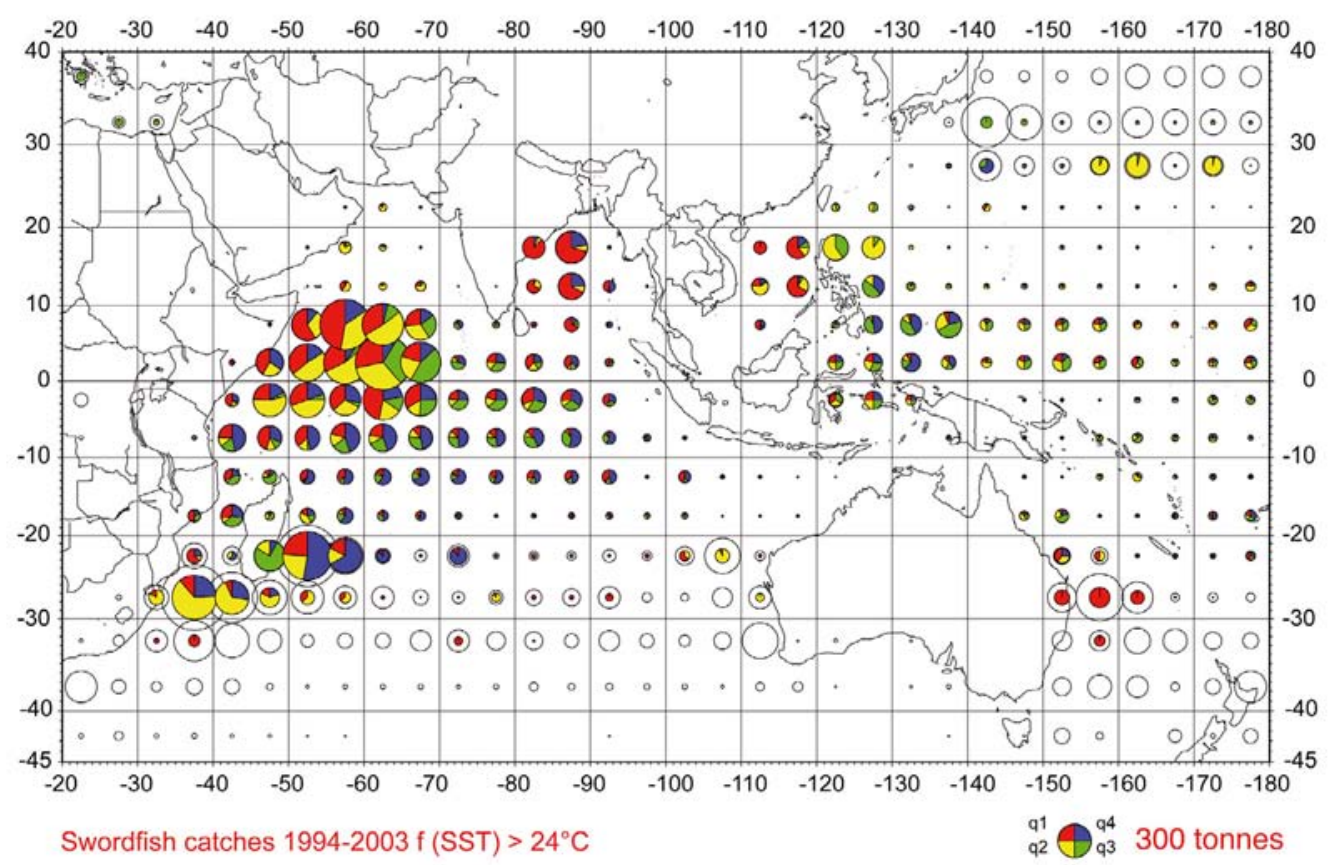

Fig. 2. Seasonal (quarterly) swordfish catch distribution. Each circle corresponds to the mean catch of swordfish in a $5^{\circ}$ square from 1994 to 2003. Circle sizes are proportional to catches. The coloured fraction of the circles corresponds to the quarterly catch in waters where temperature $>24{ }^{\circ} \mathrm{C}$ (temperature limit for spawning), whereas the uncoloured circles correspond to catches made in waters colder than $24{ }^{\circ} \mathrm{C}$ (sources: The Indian Ocean Tuna Commission-IOTC, South Pacific Commission-SPC, and NODC (Levitus) World Ocean Atlas 1994, regarding temperatures).

Females were considered to be reproductively active when GI was higher or then equal to the threshold 1.375 proposed by Hinton et al. (1997). Males were considered reproductively active when they emitted milt under moderate pressure on the testes (stages 3-4).

\subsubsection{Sex ratio at size}

Sex ratios (females/total) were established for the $5-\mathrm{cm}$ length classes within the population, and correlation and best fitting (polynomial) regression were found using Microsoft Excel software. In the Atlantic, sex ratio at size patterns have been used to characterize spawning, feeding and transition regions in the North Atlantic swordfish stock, as described by Hoey (1986); Arocha et al. (1994); Mejuto et al. (1998) and Ortiz (2000).

\subsection{Fish distribution in the Indian Ocean}

In order to explore possible movement patterns and potential high concentrations of reproducing swordfish, the seasonal (quarterly) mean catch of swordfish per $5^{\circ}$ square, between 1994 and 2003 was obtained from international databases of Indian Ocean Tuna Commission (IOTC) and South Pacific Commission (SPC). These catches were represented on a map of the whole Indian Ocean (Fig. 2), according to sea surface temperature (SST) from the World Ocean Atlas 1994, data provided by the NOAA-CIRES Climate Diagnostics Center,
Boulder, Colorado, USA, from their Web site at http://www. cdc.noaa.gov/.

In addition, to give an updated picture of swordfish reproductive dynamics, we reviewed all available key information (gonad analyses and larvae occurrence) pertaining to the spatial distribution of putative reproductive areas in Indian and west Pacific Oceans, and collated this on another map, adding the major ocean currents.

\section{Results}

\subsection{Oocyte diameter distributions}

Frequency distributions of oocyte diameter in swordfish ovaries showed maturity stages 3 to 6 (Fig. 3). At early stages of development, at which vitellogenesis is not triggered (stages 1-2, Fig. 4a), the texture of the gonad tissue did not allow oocyte dissociation and measurement.

At stage 3, oocyte diameters were normally distributed and ranged from 200 to $500 \mu \mathrm{m}$. This stage corresponds to the beginning of vitellogenesis in adult females or young ones developing towards their first maturation.

At stage 4, during full vitellogenesis, the diameters of oocytes at different stages of development ranged from 200 to $800 \mu \mathrm{m}$. The juxtaposition of yolked oocytes of different size (Fig. 4b) illustrates the asynchronous character of swordfish vitellogenesis.

At stage 5, the distribution showed a bimodal shape, which clearly differentiates vitellogenic oocytes distributed from 700 

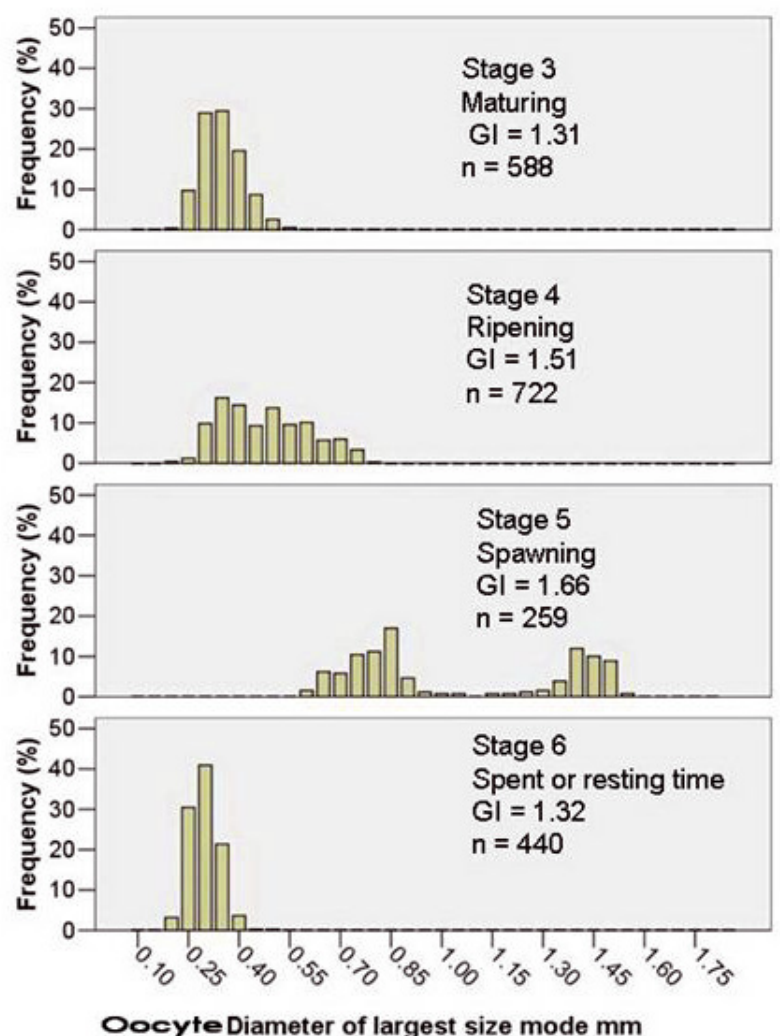

Fig. 3. Frequency distributions of oocyte diameter from maturity stages 3 to 6 for female swordfish caught by the Reunion swordfish longline fishery (see also Fig. 4). The largest size class mode of oocytes is presented with the number of oocytes and the Hinton et al. index values (GI).

to $900 \mu \mathrm{m}$ with a negative skew from hydrated oocytes of between 1200 and $1550 \mu \mathrm{m}$. Histology showed either migrating nuclei (Fig. 4c) and/or hydrated oocytes, which characterize final maturation and proximity of ovulation and spawning (Fig. 4d), or occurrence of empty follicles and/or post ovulatory follicles indicating a recent spawning (Fig. 4b).

At stage 6, the mode was centered on $300 \mu \mathrm{m}$. Histologically, the ovaries showed either oocytes undergoing early atresia, featured by zona radiata breakdown or specific signs of late resorption with oocytes surrounded by numerous layers of mesodermic tissue (Fig. 4f).

\subsection{Gonadal indexes (GI)}

The gonadal indexes for both sexes varied seasonally. For females, GI increased steadily from October to reach a maximum around February /March, then decreased (Fig. 5a) from April to July, and remained very low during the next 3 months. The mean $G I$ was above the threshold $(G I>1.375)$ from October to April.

The variations of mean $G I$ for males were synchronized with that observed in females although the amplitude was lower. The mean GI, which did not exceed 0.4, was low during the austral winter months (July to September), then a rapid recrudescence was observed between September and October followed by a 6 month period of high GI (Fig. 5a).

Gonadal maturation and reproductive activity took place in summer conditions and spawning in particular occurred when temperature was above $24^{\circ} \mathrm{C}$ (Figs. 5a,b).

\subsection{Size at first maturity $\left(L_{50}\right)$}

The number of individuals per 5-cm $L J F L$ class ranged from 1 to 31 for females, and from 1 to 27 individuals for males. The smallest spawning female sampled had a length of $127 \mathrm{~cm}($ LJFL) and its gonads weighed $1920 \mathrm{~g}$. The smallest ripe male was $101 \mathrm{~cm} L J F L$ and its testes weighed $5 \mathrm{~g}$.

The best fitting regressions of percentage of mature females and mature males on fish LJFL were logistic curves (Fig. 6) described by the following equations:

$$
\begin{aligned}
\% \text { Mature females }= & 100[1 /(1+\exp (16.2506 \\
& -0.095342 \operatorname{LJFL}))], r^{2}=0.998 \\
\% \text { Mature males }= & 100[1 /(1+\exp (10.1758 \\
& -0.084884 L J F L))], r^{2}=0.994
\end{aligned}
$$

The $L_{50} \mathrm{~s}$ were $170.4 \pm 2.1 \mathrm{~cm}$ for females and $119.9 \pm 2.1 \mathrm{~cm}$ for males ( $L J F L \pm 95 \%$ confidence interval).

\subsection{Seasonal patterns of fish size distribution}

Monthly size frequency distribution by sex showed that sizes fluctuated seasonally with a common pattern for both sexes, although the amplitude of variation was higher in the female population. The largest swordfish were caught in November at the beginning of the reproductive season. For both sexes, significant differences in size were observed between spawning and non-spawning seasons (Fig. 7a). The lowest mean sizes for both sexes were observed during the resting phase, from May to September.

\subsection{Sex ratio}

The sex ratio over all samples was 1.8:1 (F:M), which significantly differed from the expected $1: 1\left(\chi^{2}=158.86\right.$; $p<0.05$ ) (Table 3). However, the sex ratio within catches varied through the year; female swordfish significantly outnumbered males each month up to three times, except in January, February and October (Fig. 7b). Sex ratio increased as soon as the SST declined, and also decreased in October just before the SST increased. This high sensitivity of sex ratio to SST may indicate some sex specific movement towards warmer waters where breeding occurs. Finally, sex ratio also varied with fish size. In October, at the beginning of the spawning season, we noticed a sharp decrease of the sex ratio (almost equal to 1) with a concurrent increase in average body length of both sexes. It is likely that the largest females are not caught by longline fishing during the spawning season and were thus absent from the samples.

A strong prevalence of females was observed for fish between 120 and $140 \mathrm{~cm} L J F L$ and over $190 \mathrm{~cm} L J F L$ while sex 

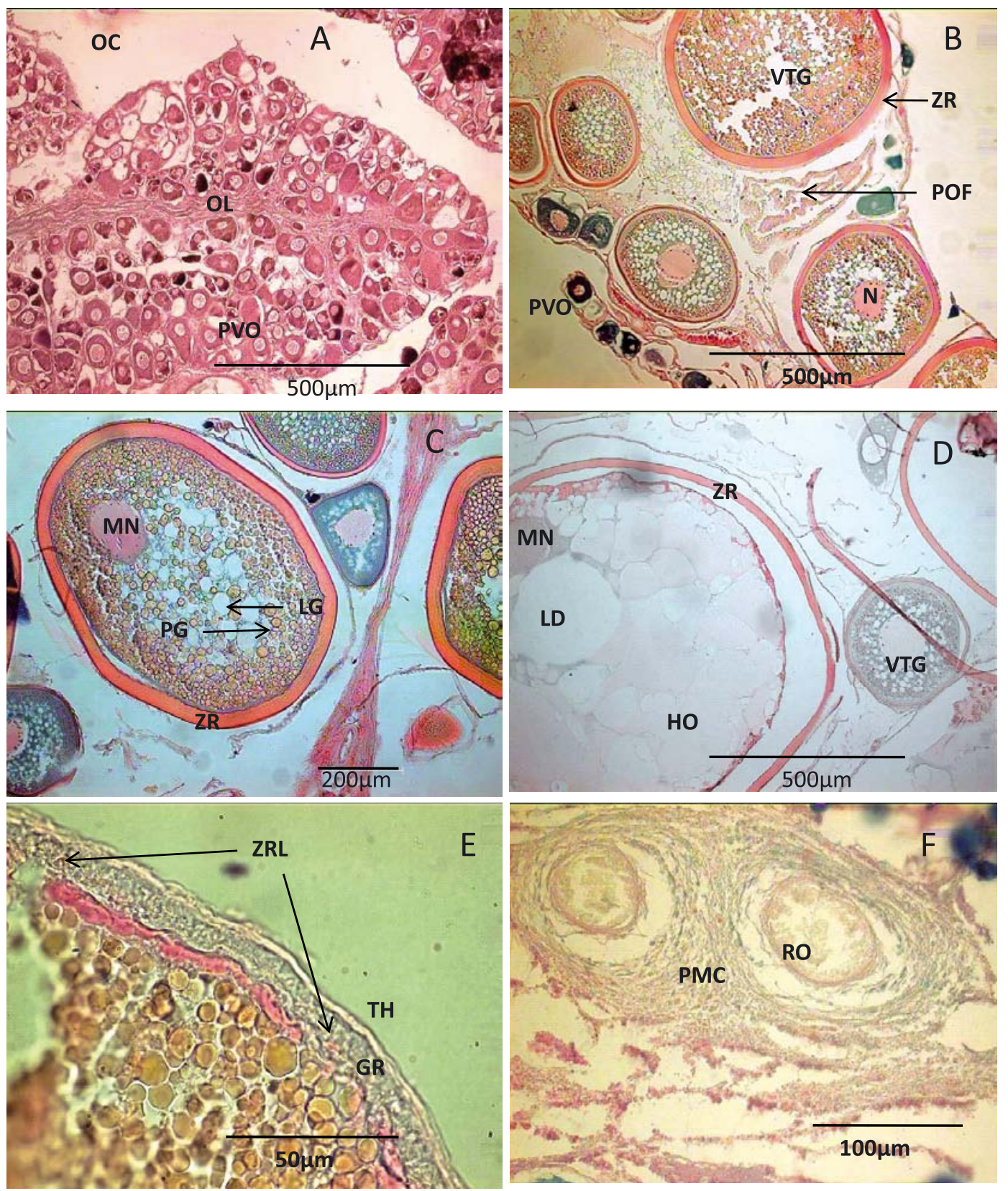

Fig. 4. Different stages of southwestern Indian Ocean swordfish (Xiphias gladius) oogenesis; a: ovary of previtellogenic female; b: asyncrhonous vitellogenesis; $\mathbf{c}$ : initiation of oocyte maturation; $\mathbf{d}$ : hydrating oocyte before meiosis resumption; e: oocyte detail at the beginning of atresia; f: final stage of oocyte resorption. GR: granulosa; HO: hydrating oocyte; LD: lipid droplet; LG: lipidic globule; MN: migrating nucleus; N: Nucleus; OC: ovarian cavity; OL: ovigerous lamella; PG proteic granules; PMC: phagocyting mesodermic cells; POF: post ovulatory follicle; PVO: previtellogenic oocytes; RO: resorbing oocytes; Th: theca; VTG: vitellogenic oocytes; ZR: zona radiata; ZRL: zona radiata leakages.

ratio was balanced for fish around $1 \mathrm{~m}$ long and between 150 and $180 \mathrm{~cm} L J F L$. A polynomial relationship was used to predict the proportion of females according to fish length between 105 and $230 \mathrm{~cm} \mathrm{LJFL} \mathrm{(Fig.} \mathrm{8).}$

\subsection{Spatio-temporal analysis of catches}

Swordfish were widely distributed but mainly caught in the western part of the Indian Ocean in waters above $24^{\circ} \mathrm{C}$
(Fig. 2), as is the case in the western Pacific Ocean and also in the Bay of Bengal. This highlights fish abundance and/or high catchability by longliners in these areas. Reproduction was observed by the occurrence of hydrated or late vitellogenic females in the second and the third quarters of the year in the northwestern Indian Ocean and in the first and the fourth quarters in the area surrounding Reunion Island. So reproduction therefore occurred under similar conditions of SST and seasonal light regimes (spring and summer) in northern and southern hemispheres. In contrast, large catches in colder 

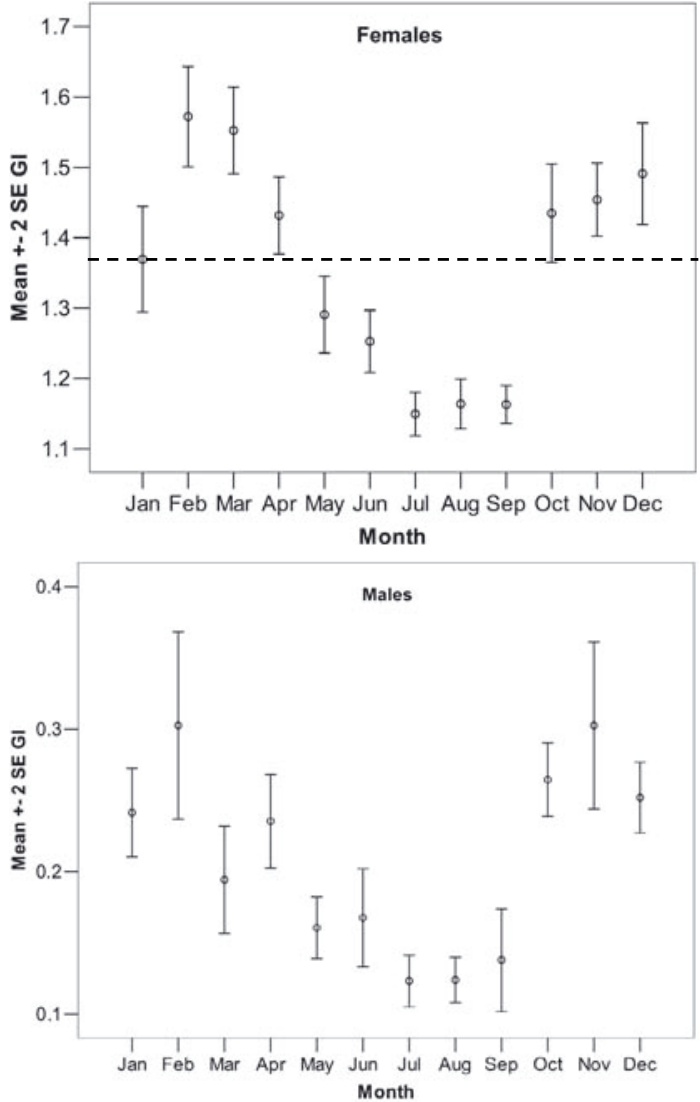

Fig. 5. Mean monthly gonadal indexes and standard error (vertical lines) for swordfish collected in the vicinity of Reunion Island; (a) females $(L J F L>165 \mathrm{~cm})$; females were considered to be reproductively active when GI higher or equal to the threshold value 1.38 (dashed line) (Hinton et al. 1997); (b) males.

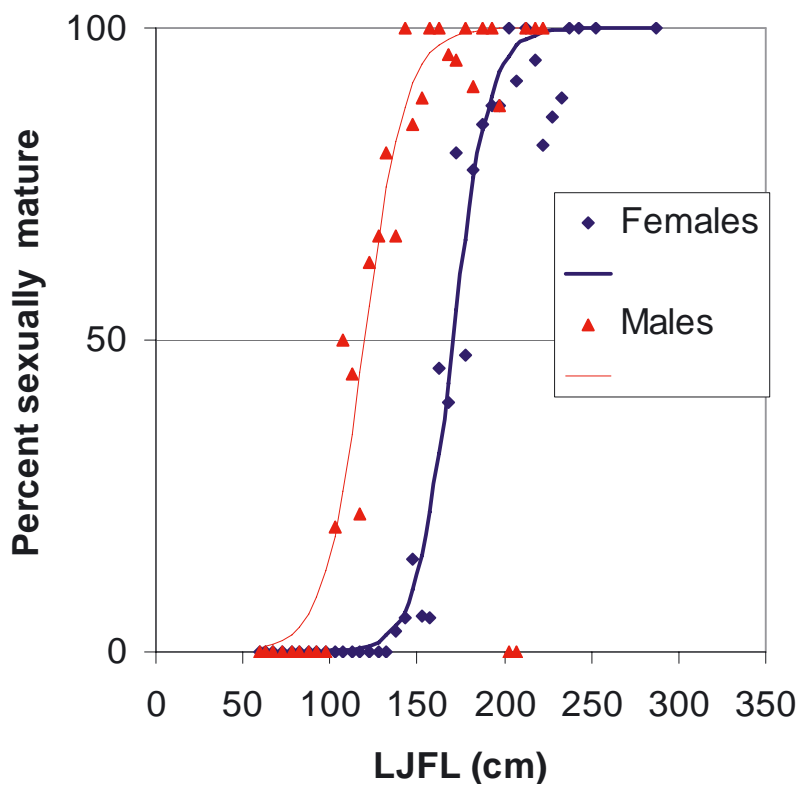

Fig. 6. Nonlinear regression fits of the logistic model for sexually mature female and male swordfish (Xiphias gladius) $L J F L-5 \mathrm{~cm}$ class, caught by the Reunion pelagic longline fishery from May 1998 to January 2001. Symbols represent mean proportions of mature ind. per 5-cm LJFL class.
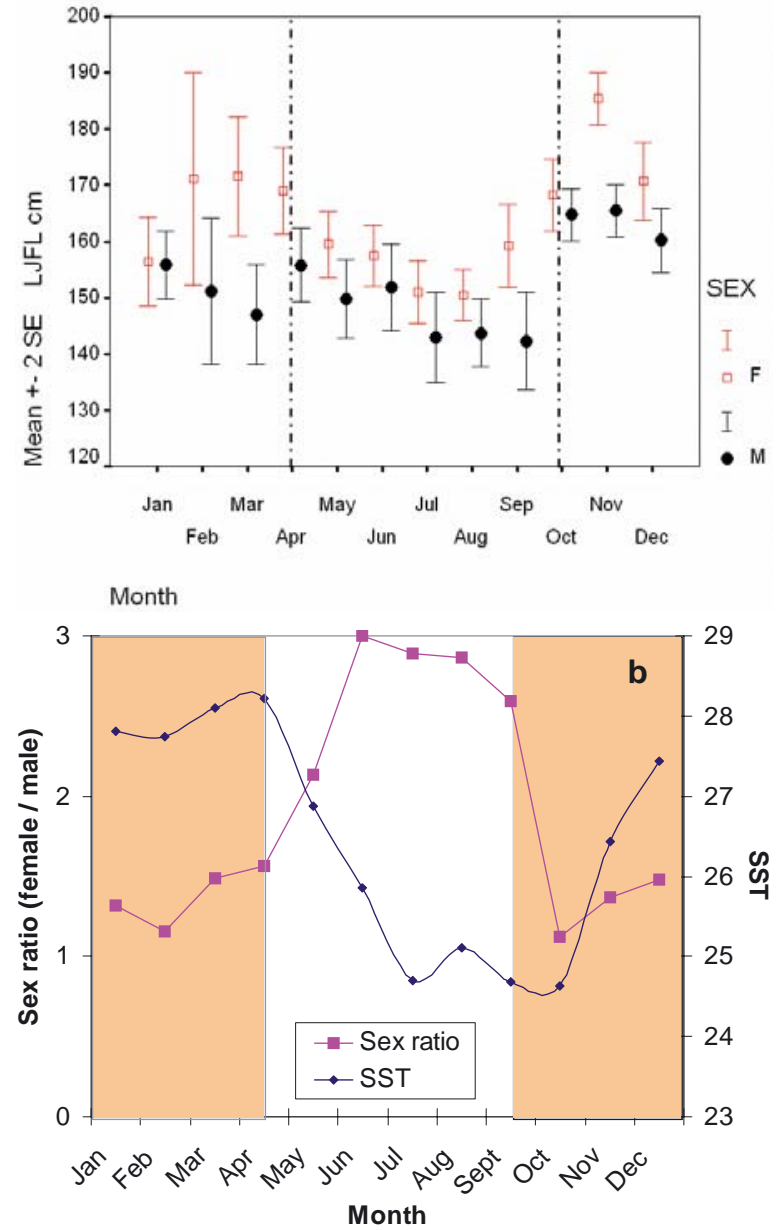

Fig. 7. (a) Monthly average length of female and males. The numbers indicate the sample sizes. Dotted lines show the spawning season period between October and April. (b) Monthly sex ratio (female/male) of swordfish (Xiphias gladius) caught by the Reunion-based pelagic longline fishery from May 1998 to January 2001. Monthly mean sea surface temperature $\left({ }^{\circ} \mathrm{C}\right), 20$ nautical mile west of Reunion Island obtained from (IRD/SEAS) between 1996 and 1998. Shade area, dotted lines show the spawning season period between October and April.

Table 3. Numbers of female and male swordfish (Xiphias gladius) collected in the vicinity of Reunion Island over the study period, and monthly comparisons of sex ratio using $\chi^{2}$ values with a sex ratio value of 1 .

\begin{tabular}{lrrrr}
\hline \multicolumn{1}{c}{ Month } & Female & Male & Sex ratio & \multicolumn{1}{c}{$\chi^{2}$} \\
\hline January & 82 & 62 & 1.32 & 2.78 \\
February & 22 & 19 & 1.16 & 0.22 \\
March & 61 & 41 & 1.49 & $3.92^{*}$ \\
April & 120 & 77 & 1.56 & $9.39^{*}$ \\
May & 119 & 56 & 2.13 & $22.68^{* *}$ \\
June & 159 & 53 & 3.00 & $53.00^{* *}$ \\
July & 104 & 36 & 2.89 & $33.03^{* *}$ \\
August & 169 & 59 & 2.86 & $53.07^{* *}$ \\
September & 70 & 27 & 2.59 & $19.06^{* *}$ \\
October & 115 & 103 & 1.12 & 0.66 \\
November & 133 & 97 & 1.37 & $5.63^{*}$ \\
December & 105 & 71 & 1.48 & $6.57^{* *}$ \\
Total & 1259 & 701 & 1.80 & $158.86^{* *}$ \\
\hline
\end{tabular}

$* p<0.05 ; * * p<0.01$. 


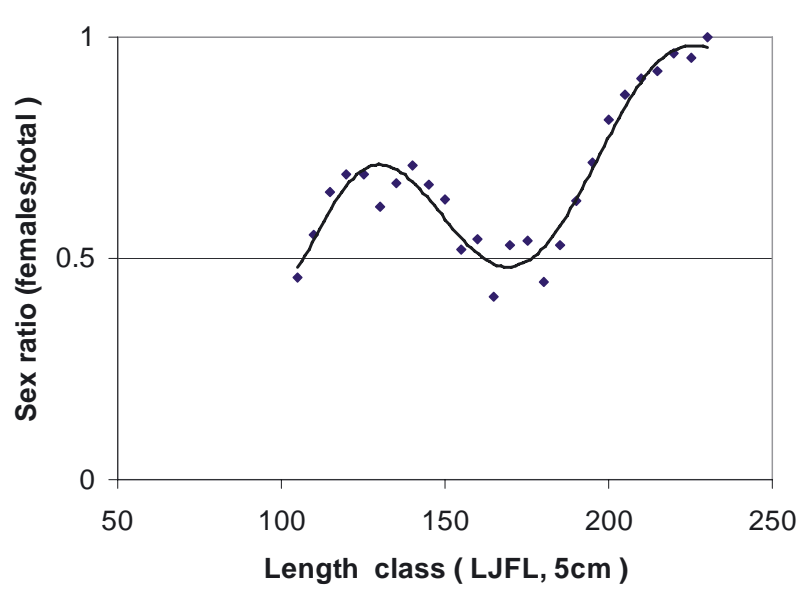

Fig. 8. Polynomial relationship between sex ratio and lower jaw-tofork length (LJFL, $5-\mathrm{cm}$ class) of swordfish $(105 \mathrm{~cm} \leqslant L J F L \leqslant$ $230 \mathrm{~cm}) ; Y=-1.2 \times 10^{-11} X^{6}-1.2 \times 10^{-8} X^{5}+5 \times 10^{-6} X^{4}-0.0011 X^{3}+$ $0.1355 X^{2}-8.3638 X+209 ; r^{2}=0.944$.

waters took place outside of the reproductive season, for example in the south Mozambique Channel in austral autumn and winter, although these swordfish were not known to be reproductively active. Figure 9 displays the different areas previously characterized as reproductive zones. The information collected in the different zones is reviewed in Table 4. In the area off Taiwan (area "e"), females with vitellogenic oocytes were observed but no hydrated oocytes were found. In addition, the different areas where larvae were collected are shown on the map. Moreover, the main ocean currents possibly involved drift of fish or larvae are also represented.

\section{Discussion}

\subsection{Gonad maturity}

In this study, we inferred the pattern of swordfish reproductive dynamics from a combination of morphological assessment of gonads, gonadal index, oocyte size distribution and histology over 3 consecutive annual reproductive cycles. With reference to assessment of female reproductive activity by Hinton et al. (1997), swordfish in the vicinity of Reunion Island would be sexually active from October to April $(G I>1.375)$. However, although DeMartini et al. (2000) predicted reproductive activity of swordfish caught by the Hawaii based fishery with $>90 \%$ accuracy using the same index, Wang et al. (2003) found ripening females, based on histological observation, with a GI below 1.375 and concluded that Hinton et al.'s threshold was not completely suitable for swordfish in Taiwanese waters. In the current work, regressed or resorbing females showed high gonadal indexes, nevertheless, the regressing females may have spawned recently. Histological study, which is the most accurate method for classifying fish maturity (West 1990; DeMartini 2000; Young et al. 2003), confirmed that recently spent females with high GI may exhibit post ovulatory follicles together with oocytes with zona radiata breakdown. In such conditions, although not precise, the threshold proposed by Hinton was acceptable to define the limits of spawning season in the studied area. The synchronization of GI variations between males and females on the geographic zone indicates that conditions for breeding are met.

The study of oocyte diameter distribution and the occurrence of post ovulatory follicles concomitant with maturational oocytes with migrating nuclei or hydration confirmed that females are multiple spawners with asynchronous oocyte development, as observed by Arocha (2002).

\subsection{Sex ratio and fish size}

In the vicinity of Reunion Island, the sex ratio was almost balanced during austral summer and autumn whereas females outnumbered males during the rest of the year.

Such a pattern was also underlined by Young et al. (2003) off eastern Australia. In the western North Atlantic, off the Florida coast and off Cuba, Guitard Manday (1964) and Taylor and Murphy (1992) noticed that males outnumbered females during spawning season. Rapid sex ratio shift could provide an accurate proxy for determining reproductive activity, as noted by Ortiz et al. (2000) for North Atlantic swordfish.

Swordfish ageing studies showed differential sex dependant growth patterns in the Atlantic Ocean, (Berkeley and Houde 1983; Ehrhardt 1992; Esteves et al. 1995; Ehrhardt et al. 1996); the Pacific Ocean (Sun et al. 2002); Mediterranean Sea (Tsimenides and Tserpes 1989; Megalofonou et al. 1995; Tserpes and Tsimenides 1995), as well as in Indian Ocean (Vanpouille et al. 2001). Swordfish females grow faster and achieve larger size than males (DeMartini et al. 2007). As males probably mature earlier, energy would be directed to reproductive activity rather than growth (Ehrhardt 1999; DeMartini et al. 2000).

Sex ratio and body length variations noticed off Reunion Island suggest that larger individuals of both sexes reach this area when the reproduction starts.

We hypothesize that large individuals could come from south of Madagascar and South African cold and energy-rich waters that could be identified as a "Feeding region". As with other billfishes, the migration patterns of swordfish involve seasonal movement into temperate or cold waters for feeding and a return to subtropical waters for over-wintering and spawning (Nakamura 1986; Takahashi et al. 2003).

However, at the Equator, in the Seychellese waters, Wendling et al. (2002) reported that the average size of swordfish was smaller than in subtropical waters and that the largest sizes of swordfish were recorded between May and August, corresponding to the non-spawning period off Reunion Island. They also showed that males predominated significantly almost all year round. Opposing trends and seasonal variations in sex ratio and size of captured fish between the Seychelles and Reunion Island may suggest a synchronized movement related to spawning.

Spawning begins in early October. Older, larger individuals may mature before younger, smaller fish and could be the first to arrive and start spawning. As the spawning season progresses, swordfish caught later in the season are younger, smaller component of the population.

Stanley (2006), despite a low tag recapture return rate, showed that main movements for swordfish off eastern and western Australian coast were latitudinal and not longitudinal. 


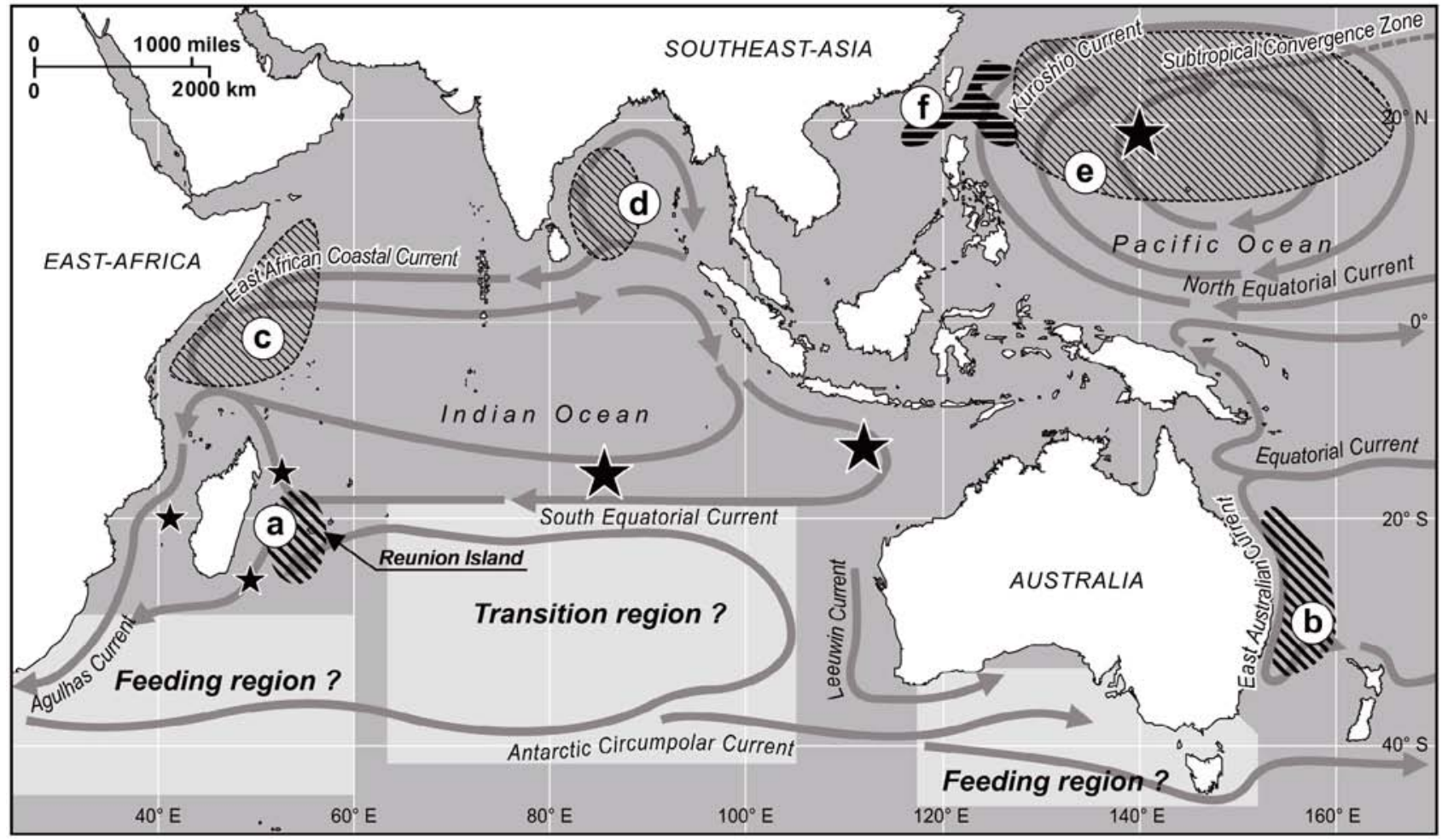

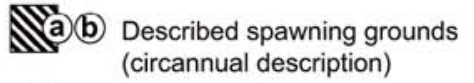

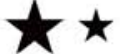

swordfish larvae (High and low distribution) (c) (d) (e) Collection of females with hydrated ovocytes

Direction of ocean currents
Ef Mature females but no case of observed hydrated oocytes

Fig. 9. Map showing all available information on the reproductive biology of swordfish in Indian Ocean and in the western Pacific Ocean.

Large fish, especially females, have a high physiological tolerance for cold water temperatures (Palko et al. 1981; Hoey 1991), and are dominant in higher latitudes (Sakagawa 1989). These large fish could migrate towards spawning grounds and then move back to and gain condition in highly productive areas afterwards (Arocha 2007).

As tagging data in other oceans indicate that swordfish are capable of large-scale movements at the oceanic scale (Holts et al. 1994; Caddy 1976; Takahashi et al. 2003), we presumed that males could only move south from equator to the warm subtropical waters during summer. Predominance of males at the equator and low tolerance to cold temperature has been reported by Beckett (1974) and by Young et al. (2003).

Besides the movements of fractions of the swordfish population off Reunion Island, the domestic fleet continued catching swordfish using the same fishing techniques and strategy, during winters, especially on the seamounts located to the west and south of the island. Thus, Carey and Robinson (1981) and Sedbery and Loefer (2001), mentioned the existence of localized sub-populations associated with the regional environment features. Only a large scale sampling program with a sufficient number of recaptures could provide information of sufficient quality on migration and homing patterns.

\subsection{Size-at-maturity}

The estimated length-at-maturity for females from our samples was comparable to those estimated based on histological analysis in the Pacific Ocean on Eastern coast of Australia (Young et al. 2000) and in the waters of Taiwan (Wang et al. 2003). The size-at-maturity for swordfish was studied worldwide except in the Indian Ocean. Differences between the sizeat-maturity estimates have obviously to be linked to the stock units (Arocha 2007) but may also be methodological. Yabe et al. (1959) estimates were based on macroscopic observation of the gonads combined with a length-ovary weight relationship. Some authors used gonadal indexes, which were not particularly sensitive to reproductive state. However, DeMartini (2000) predicted using histological analysis that $L_{50}$ was lower than our result. In this case, differences may be due to the latitude ranges (and different environmental conditions between the two oceans) covered by the study, different stock units, or limited spatial sampling of the reproductive population in the Indian Ocean. De Metrio et al. (1995); De la Serna et al. (1995) predicted the smallest estimates of $L_{50}$ for female swordfish in the Mediterranean sea. As expected from previous work by Uchiyama et al. 1998), Ehrhardt et al. (1996) and Wang et al. (2001), male swordfish in the area off Reunion Island matured at a much shorter length than females. 
Table 4. Summary of information about reproductive biology of swordfish in the Pacific and Indian Oceans.

\begin{tabular}{|c|c|c|c|}
\hline Areas* and period & Authors & $\begin{array}{c}\text { Main } \\
\text { information }\end{array}$ & Research conducted \\
\hline East coast of Madagascar & Lütken (1880) & $\begin{array}{l}\text { Occurrence of } \\
\text { swordfish larvae }\end{array}$ & Larvae survey \\
\hline $\begin{array}{l}\text { Area "e", in the southern } \\
\text { waters of the subtropical } \\
\text { convergence }\end{array}$ & $\begin{array}{l}\text { Yabe et al. (1959), } \\
\text { Nishikawa } \\
\text { and Ueyanagi } \\
\text { (1974). }\end{array}$ & $\begin{array}{l}\text { Occurrence of } \\
\text { swordfish larvae }\end{array}$ & Larvae survey \\
\hline $\begin{array}{l}\text { South east of Sumatra } \\
\text { between } 12-17^{\circ} \mathrm{S} \text { and } 85-87^{\circ} \mathrm{E} \text {, } \\
\text { corresponding to the } \\
\text { South Equatorial current }\end{array}$ & $\begin{array}{l}\text { Bogorov and } \\
\text { Rass (1961) }\end{array}$ & $\begin{array}{l}\text { Occurrence of } \\
\text { swordfish larvae }\end{array}$ & Larvae survey \\
\hline Mozambique Channel & $\begin{array}{l}\text { Gorbunova } \\
(1969) \\
\text { Kondritskaya } \\
\text { et al. (1970) }\end{array}$ & $\begin{array}{l}\text { Occurrence of } \\
\text { swordfish larvae, } \\
\text { at the end of January }\end{array}$ & Larvae survey \\
\hline $\begin{array}{l}\text { Offshore the north western } \\
\text { Australian coast and in the } \\
\text { south east of java }\end{array}$ & $\begin{array}{l}\text { Occurrence of } \\
\text { Nishikawa et al. } \\
(1985)\end{array}$ & swordfish larvae & Larvae survey \\
\hline $\begin{array}{l}\text { Area "f", Taiwanese waters } \\
\text { Sept. 1997- July } 2000 .\end{array}$ & $\begin{array}{l}\text { Wang et al. } \\
\text { (2003) }\end{array}$ & $\begin{array}{l}\text { Occurrence of mature } \\
\text { female; no } \\
\text { hydrated oocytes. } \\
\text { Spawning ground off } \\
\text { the Taiwanese coast } \\
\text { (area "e" southern } \\
\text { waters of the } \\
\text { subtropical } \\
\text { convergence) }\end{array}$ & $\begin{array}{l}\text { - Assessment of reproductive activity } \\
\text { (histology, gonadal index, maximum } \\
\text { oocyte size) } \\
\text { - Size at first maturity estimates }\left(L_{50}\right) \\
\text { for males and females } \\
\text { - Sex ratio and sex ratio at size }\end{array}$ \\
\hline $\begin{array}{l}\text { Area "c", off Somalia } \\
\text { coast } 10^{\circ} \mathrm{N} / 5^{\circ} \mathrm{S} \text { and } 40 / 55^{\circ} \mathrm{E} \\
\text { Sampling between } 1993 \\
\text { and } 2004\end{array}$ & $\begin{array}{l}\text { Mejuto et al. } \\
(2006)\end{array}$ & $\begin{array}{l}\text { occurrence of females } \\
\text { with hydrated / } \\
\text { transparent oocytes. } \\
\text { Potential spawning area }\end{array}$ & $\begin{array}{l}\text { - Assessment of reproductive activity } \\
\text { (gonadosomatic index) } \\
\text { - Sex ratio and sex ratio at size }\end{array}$ \\
\hline $\begin{array}{l}\text { Area "b", off eastern } \\
\text { Australia and New Zealand } \\
\left(20 / 35^{\circ} \mathrm{S} \text { and } 153 / 165^{\circ} \mathrm{E}\right) \\
\text { May 1999-March } 2001\end{array}$ & $\begin{array}{l}\text { Young et al. } \\
\text { (2003) }\end{array}$ & $\begin{array}{l}\text { Spawning ground } \\
\text { September to March }\end{array}$ & $\begin{array}{l}\text { - Assessment of reproductive activity } \\
\text { (histology, gonadal index, maximum } \\
\text { oocyte size) } \\
\text { - Size at first maturity estimates }\left(L_{50}\right) \\
\text { for males and females } \\
\text { - Sex ratio and sex ratio at size } \\
\text { - Batch fecundity estimates (gravimetric method) }\end{array}$ \\
\hline $\begin{array}{l}\text { Area "a", off Reunion } \\
\text { Island } \\
\text { May 1998-January } 2001\end{array}$ & Current study & $\begin{array}{l}\text { Spawning ground } \\
\text { October to April }\end{array}$ & $\begin{array}{l}\text { - Assessment of reproductive activity } \\
\text { (histology, gonadal index, maximum } \\
\text { oocyte size) } \\
\text { - Size at first maturity estimates }\left(L_{50}\right) \\
\text { for males and females } \\
\text { - Sex ratio and sex ratio at size } \\
\text { Batch fecundity estimates (gravimetric method) }\end{array}$ \\
\hline
\end{tabular}

*Areas are indicated in Fig. 9.

\subsection{Spawning areas}

We found that the reproductive period off Reunion Island (between $19-25^{\circ} \mathrm{S}$ and $48-54^{\circ} \mathrm{E}$ ) started in October when sea surface temperatures (SST) were above $24{ }^{\circ} \mathrm{C}$, suitable conditions for larvae to survive (Govoni et al. 2003). The values of sex ratio at size in the area showed clearly a 'spoon shape' pattern which is characteristic of spawning areas, according to Mejuto et al. (1998). Our results agreed with those of Young et al. (2002), who also identified 7-month spawning season: at higher latitudes but starting earlier, from September to March, on the eastern coast of Australia, between 20 and $35^{\circ} \mathrm{S}$.

These results are consistent with the literature; swordfish are known to spawn in tropical and subtropical areas located in the western parts of oceans, in localized areas relatively close to coastal waters (Taylor and Murphy 1992; Arocha and Lee 1995), and in spring and summer at higher latitude, when SST exceeds $24{ }^{\circ} \mathrm{C}$ (Ward and Elscot 2000; Arocha 2007). In the southern hemisphere, high catches during the first and fourth quarter of the year around Reunion Island, and during the first 
quarter on the east coast of Australia are close agreement with previous findings.

In the northern hemisphere part of the Pacific Ocean, Wang et al. (2003) found mature females in the vicinity of Taiwan. Their study indicated that swordfish do not spawn in Taiwanese waters, but more likely in the southern waters of the subtropical convergence zone in the North Pacific: a scenario earlier suggested by Yabe et al. (1959). Mejuto et al. (2006) reported high values of gonadal index between $10^{\circ} \mathrm{N}$ and $5^{\circ} \mathrm{S} /$ $40^{\circ} \mathrm{E}$ and $55^{\circ} \mathrm{E}$, with reports from scientific observers indicating that all the females $>150 \mathrm{~cm}$ LJFL had hydrated eggs in their ovaries suggesting that this area could be a potential spawning area. In these two areas, spawning is likely to occur during the second and the third quarters of the year, at the same time as when the main catches are recorded.

In the Indian Ocean, more investigations are needed in the northern hemisphere and at the equator to define spawning areas but also spawning peaks. The equatorial belt is a probable spawning area but not one of intense reproduction.

There were substantial swordfish catches in the Bay of Bengal, but outside of the spawning season generally observed in north hemisphere. Nevertheless, this semi-enclosed area could exhibit specific oceanographic features compatible with swordfish reproduction requirements. Yabe et al. (1959) collected matured ovaries in April in the area between the equator and the Bay of Bengal and suggested that the spawning season would occur after April.

Yabe et al. (1959) also reported the occurrence near the equator of spawning individuals in April and juveniles in August, November and December. Larvae were also collected off the east coast of Madagascar (Lütken 1880 in Palko et al. 1981 and Gorbunova 1969) and in the Mozambique Channel at the end of January (Kondritskaya 1970). Nishikawa et al. (1985) reported highest concentrations of swordfish larvae in the northeast of the Indian Ocean (offshore the northwestern Australian coast and in the southeast of Java) (Fig. 9). The occurrence of swordfish larvae was reported by Bogorov and Rass (1961, cited in Palko et al. 1981) to the southeast of Sumatra, more specifically between $12-17{ }^{\circ} \mathrm{S}$, corresponding to the south equatorial current, and between $85-87^{\circ} \mathrm{E}$ and 5$17{ }^{\circ} \mathrm{S}$. While it could be assumed from this data that the areas where larvae were collected correspond more or less to the spawning location, according to Govoni et al. (2000), it is sometimes difficult to draw conclusions about spawning areas as "large and presumably older larvae in any location may be the result either of local spawning and subsequent retention or of transport from distant spawning locale".

According to our findings about possible movements of large individuals, we assumed that the southern part of the Mozambique Channel and Madagascar, and the southern part of Australia could be identified as two "feeding regions" for swordfish. Mimira (1962) suggested that the southern part of Australia, located in the West Wind Drift, was a feeding area for the southern bluefin tuna. Between these two "feeding regions", we suggest that the central Indian Ocean could be a "transition region".

\section{Conclusion}

Information on the life history of swordfish in the Indian Ocean is scarce and patchy. Our different measurement approaches, comprising swordfish size, sex and gonads, carried out using commercial fleet catches from Reunion Island during a three year survey, showed that the species meets suitable conditions for reproduction in this area.

As a spawning ground, the Reunion Island area is characterized by a differential abundance/catchability of swordfish by sex throughout the year that provides some preliminary indications of synchronized movements of swordfish between spawning grounds and neighboring regions.

A 7-month spawning period was observed, closely linked to SST, during which the females lay successive batches of eggs at a non evaluated frequency.

Complementary investigations are needed to gain an ocean-wide understanding, the location and timing of spawning along the associated migration patterns. Ichthyoplankton surveys should be used to define spawning grounds, spawning seasons and spawning peaks. As swordfish recapture rates are likely to be very low, the pop-up satellite-transmitting archival tag (PSTAT) should be appropriate to get valuable information on swordfish movement in the Indian Ocean. Knowledge of spatial distribution of larvae and migration pattern of the spawning stock are key issues for the regulation of this fishery.

Acknowledgements. This project was an IFREMER programme financed by the European Union (FEDER), and the Conseil Régional and Conseil Général de La Réunion.

The authors would like to express their gratitude to the skippers who volunteered to allow scientific observers on board their vessels and to all people involved in the sampling. We thank the fishery industry of Reunion Island for their outstanding support of the "Programme Palangre Réunion” ( $P P R)$ project. We thank Bernard Stéquert for his helpful advice and suggestions during the study. We are also grateful to the anonymous referees for their helpful comments on the manuscript, and finally wish to thank Pierre Lopez and Alain Fonteneau for their input on the improvement of the illustrations in this paper.

\section{References}

Anonymous, 2007, Report of the 10th Session of the Scientific Committee Victoria, Seychelles, 5-9 Nov. 2007.

Arocha F., 2002, Oocyte development and maturity classification of swordfish from the north-western Atlantic. J. Fish Biol. 60, 1327.

Arocha F., 2007, Swordfish reproduction in the Atlantic Ocean: an overview. Gulf Caribb. Res. 19, 21-36.

Arocha F., Lee D.W., Grubich J.R., 1994, Observations on sex ratio, maturity stages, and fecundity estimates of swordfish, Xiphias gladius, in the Northwest Atlantic Ocean. ICCAT, Coll. Sci. Pap. 42, 309-318.

Arocha F., Lee D.W., 1995, The spawning of the swordfish from the Northwest Atlantic. ICCAT, Coll. Sci. Pap. 44, 179-186.

Arocha F., Lee D.W., 1996, Maturity at size, reproductive seasonality, spawning frequency, fecundity and sex ratio in swordfish from the Northwest Atlantic. ICCAT, Coll. Sci. Pap. 45, 350-357. 
Beckett J.S., 1974, Biology of swordfish, Xiphias gladius L., in the North-west Atlantic Ocean. In: Shomura R.S., Williams S. (Eds.) Proc. Int. Billfish Symp., Part 2, Review and contributed papers. US Dep. Commerce, NOAA Tech. Rep. NMFS, SSRF-675, pp. 105-106.

Berkeley S.A., Houde E.D., 1983, Age determination of swordfish, Xiphias gladius, in the northwestern Atlantic. Bull. Mar. Sci. 50, 292-301.

Caddy J.F., 1976, A review of some factors relevant to management of swordfish fisheries in the northwest Atlantic. Fish. Mar. Serv. Res. Dev. Tech. Rep. 633.

Carey F.G., Robinson B., 1981, Daily patterns in the activities of swordfish, Xiphias gladius, observed by acoustic telemetry. Fish. Bull. 79, 277-292.

Cayré P., Farrugio H., 1996, Reproduction biology of the skipjack (Katsuwonus pelamis) in the Atlantique Ocean. In: Symons P.E.K, Miyake P.M., Sakagawa G.T. (Eds.) ICCAT Conf. on the international skipjack year programme. ICCAT Madrid, pp. 252272.

De la Serna J.M., Ortiz de Urbina J.M., Macias D., 1995, Observations on sex ratio, maturity and fecundity by length-class for swordfish (Xiphias gladius) captured with surface longline in the western Mediterranean. ICCAT, SCRS/95/45.

DeMartini E.E., Uchiyama J.H., Williams H.A., 2000, Sexual maturity, sex ratio, and size composition of swordfish, Xiphias gladius, caught by the Hawaii-based pelagic longline fishery. Fish. Bull. 98, 489-506.

DeMartini E.E., Uchiyama J.H., Humphreys R.L. Jr, Sampaga J.D., Williams H.A., 2007, Age and growth of swordfish (Xiphias gladius) caught by the Hawaii-based pelagic longline fishery. Fish. Bull. 105, 356-367.

De Metrio G., Giacchetta F., Santamaria N, 1995, Sex ratio and gonadosomatic index of swordfish (Xiphias gladius) in the northern Ionian Sea and southern Adriatic Sea. 25th Congresso Soc. Ital. Biol. Mar. 2, 479-481.

Ehrhardt N.M., 1992, Age and growth of swordfish, Xiphias gladius, in the northwestern Atlantic. Bull. Mar. Sci. 50, 292-301.

Ehrhardt N.M., Robbins R.J., Arocha F., 1996, Age validation and growth of swordfish, Xiphias gladius, in the northwestern Atlantic. ICCAT, Coll. Sci. Pap. 45, 358-367.

Ehrhardt N.M., 1996, Review of age and growth of swordfish, Xiphias gladius, using methods other than otoliths session.2nd Int. Pacific Swordfish Symp. Hawaii, 3-6 March 1996.

Esteves E., Simoes P., Da Silva H.M, Andrade J.P., 1995, Ageing of swordfish, Xiphias gladius Linnaeus, 1758, from the Azores, using sagittae, anal-fin spine and vertebrae. Bull. Univ. Azores, Life and Marine Sciences 13A, pp. 39-51.

Gabe M., 1968, Techniques histologiques. Masson et Cie, Paris.

Gorbunova N.M., 1969, Breeding grounds and food of the larvae of the swordfish Xiphias gladius Linnaeus (Pisces, Xiphiidae). Probl. Ichthyol. 9, 375-387.

Govoni J.J., Stender B.W., Pashuk O., 2000, Distribution of larval swordfish, Xiphias gladius, and probable spawning off the southeastern United States. Fish. Bull. 98, 64-74.

Govoni J.J., Laban E.H., Hare J.A., 2003, The early life history of swordfish (Xiphias gladius) in the western North Atlantic. Fish. Bull. 101, 778-789.
Guitart Manday D., 1964, Biologia pesquera del emperador o pez de espada, Xiphias gladius Linnaeus (Teleostomi: Xiphiidae) en las aguas de Cuba. Poeyana, Ser. B, $\mathrm{N}^{\circ} 1$.

Hinton M.G., Taylor R.G., Murphy M.D., 1997, Use of gonad indices to estimate the status of reproductive activity of female swordfish, Xiphias gladius: A validated classification method. Fish. Bull. 95, 80-84.

Holts D.B., Bartoo N.W., Dennis W., 1994, Swordfish tracking in the Southern California Bight. U.S. Nat. Mar. Fish. Serv., Southwest Fish. Sci. Center, Admin. Rep. LJ 94-15: 9

Hoey J., 1986, A review of sex ratio by size data for western North Atlantic swordfish. Swordfish working paper 86/10.NMFS, SEFC, Miami.

Kondritskaya S.I., 1970, The larvae of the swordfish (Xiphias gladius L.) from Mozambique Channel. J. Ichthyol. 10, 853-854.

Lowerre-Barbieri S.K., Barbieri L.R., 1993, A new method of oocyte separation and preservation for fish reproduction studies. Fish. Bull. 91, 165-170.

Megalofonou P., Dean J.M., De Metrio G., Wilson C., Berkeley S., 1995, Age and growth of juvenile swordfish, Xiphias gladius Linnaeus, from theMediterranean Sea. J. Exp. Mar. Biol. Ecol. $188,79-88$.

Mejuto J., de la Serna J.M., Garcia B. 1998, Some considerations on the spatial and temporal variability in the sex ratio at size of the swordfish (Xiphias gladius L.). ICCAT Col. Vol. Sci. Pap. 48, pp. 205-215.

Mejuto J., García-Cortés B., Ramos-Cartelle A., 2006, An overview of research activities on swordfish (Xiphias gladius) and the bycatch species, caught by the Spanish longline fleet in the Indian ocean. IOTC 2006-WPB-11.

Miyabe N., Bayliff W.H., 1987, A review of the Japanese longline fishery for tunas and billfishes in the eastern Pacific Ocean, 19811987. Bull. IATTC 19.

Mugnier C., 1996, Analyse morphologique et endocrinienne des dernières étapes de l'ovogenèse et recherche d'un traitement de l'induction de l'ovulation chez le turbot (Scophthalmus maximus). Thèse dr, Université de Rennes I.

Nakamura I., 1986, Systematics, evolution and ecology of the billfishes (a preliminary consideration based on external morphology). In: Uyeno T., Arai R., Taniuchi T., Matsuura K. (Eds.) Proc. 2nd Int. Conference on Indo-Pacific Fishes. Ichthyol. Soc. Jap., Tokyo.

Nishikawa Y., Ueyanagi S., 1974, The distribution of the larvae of swordfish Xiphias gladius in the Indian and Pacific Oceans. In: Shomura R.S., Williams F. (Eds.) Proc. Int. billfish symposium, Kailua-Kona, Hawaï, 9-12 Aug. 1972. Part 2. Review and contributed papers. US Dep. Commerce, NOAA Tech. Rep., NMFS/ SSRF/675, pp. 261-264.

Nishikawa Y., Honma M., Ueyanagi S., Kikawa S., 1985, Average distribution of larvae of oceanic species of scombroid fishes, 1956-1981. Ser. Far Seas Fish. Res. Lab. 12.

Ortiz M., Restrepo V.R., Turner S.C., 2000, North Atlantic swordfish sex-ratios at size keys: analysis and development. Coll. Vol. Sci. Pap. ICCAT 51, 1480-1509.

Palko B.J., Beardsley G.L., Richards W.J., 1981, Synopsis of the Biology of the Swordfish, Xiphias gladius Linnaeus. FAO Fish. Synop.

Sakagawa G.T., 1989, Trends in fisheries for swordfish in the Pacific Ocean. In: Stroud R.H. (Ed.) Planning the future of billfishes. 
Proc. 2nd Int. Billfish Symposium. Kailua-Kona, Hawaii, 15 August 1988. Marine Recreational Fisheries 13. National Coalition for Marine Conservation, Inc., Savannah GA, pp. 6179.

Sedberry G.R., Loefer J.F., 2001, Satellite telemetry tracking of swordfish Xiphias gladius, off the Eastern United States. Mar. Biol. 139, 355-360.

Stanley C.A., 2006, Determining the nature and extent of swordfish movement and migration in the eastern and western AFZ through and industry-based tagging program. Canberra: Australian Fisheries Management Authority.

Stéquert B., Ramcharrun B., 1995, La fécondité du listao (Katsuwonus pelamis) de l'ouest de l'océan Indien. Aquat. Living. Resour. 8, 79-89.

Sun C., Wang S., Yeh S., 2002, Age and growth of the swordfish (Xiphias gladius L.) in the waters around Taiwan determined from anal-fin rays. Fish. Bull. 100, 822-835.

Takahashi M., Okamura H., Yokawa K., Okazaki M., 2003, Swimming behaviour and migration of a swordfish recorded by an archival tag. Mar. Freshw. Res. 54, 527-534.

Taylor R.G., Murphy M.D., 1992, Reproductive biology of the swordfish Xiphias gladius in the straits of Florida and adjacent waters. Fish. Bull. 90, 809-816.

Tserpes G., Tsimenides N, 1995, Determination of age and growth of swordfish, Xiphias gladius L., 1758, in the eastern Mediterranean using anal-fin spines. Fish. Bull. 93, 594-602.

Tsimenides N., Tserpes G., 1989, Age determination and growth of swordfish, Xiphias gladius, in the Agean Sea. Fish. Res. 8, 159-168.
Uchiyama J.H., Shomura R.S., 1974, Maturation and fecundity of swordfish, Xiphias gladius, from Hawaiian waters. US Nat. Mar. Fish. Serv., NOAA Tech. Rep. NMFS/SSRF 675, 142-148.

Vanpouille K. , Poisson F., Taquet M., Ogor A., Troadec H., 2001, Etude de la croissance de l'espadon (Xiphias gladius) L'espadon, de la recherche à l'exploitation durable. In: Poisson F., Taquet M. (Eds.) Programme Palangre Réunionnais, Rapp. final, pp. 139169.

Wang S., Sun C., Yeh S., 2003, Sex ratios and sexual maturity of swordfish (Xiphias gladius L.) in the waters of Taiwan. Zool. Stud. 42, 529-539.

Ward P., Elscot S., 2000, Broadbill swordfish: Status of world fisheries. Bureau of rural Sciences, Canberra.

Wendling B., Lucas V., Bargain R.M., Taquet M., Poisson F., 2004, Programme d'action pour la pêche palangrière seychelloise (PAPPS). (I) Les pêcheries palangrières aux Seychelles. (II) Résultats des campagnes de pêche expérimentales à bord du navire de recherche de la SFA "L'Amitié", 2000-2002. Seychelles Fishing Authority, Seychelles.

West G., 1990, Method of assessing ovarian development in fishes: a review. Aust. J. Mar. Freshw. Res. 41, 199-222.

Yabe H., Ueyanagi S., Kikawa S., Watanabe H., 1959, Study on the life history of the swordfish (Xiphias gladius) Linnaeus. Rep. Nankai Reg. Fish. Res. Lab. 10, 107-150.

Young J., Drake A., Brickhill M., Farley J., Carter T., 2003, Reproductive dynamics of broadbill swordfish, Xiphias gladius, in the domestic longline fishery off eastern Australia. Mar. Freshw. Res. 54, 315-332. 